\title{
Determinants of personal tax compliance
}

\author{
Subadriyah $^{\mathrm{a}, \mathrm{b}^{*}}$ and Puji Harto ${ }^{\mathrm{a}}$
}

${ }^{a}$ Universitas Diponegoro, Semarang, Indonesia

${ }^{b}$ Nahdlatul Ulama Islamic University, Jepara, Indonesia

C H R O N I C L E

\section{Article history:}

Received: February 27, 2021

Received in revised format:

April 292021

Accepted: May 3, 2021

Available online:

May 3, 2021

Keywords:

Taxpayer compliance

Quality of tax services

Tax sanctions

Tax socialization

Employment status

\section{A B S T R A C T}

The largest state revenue comes from taxes. Even though the number of taxpayers is increasing from year to year, the tax revenue in Indonesia is still relatively low, since taxpayer compliance is still low. This study aims to determine the factors that influence individual taxpayer compliance in paying taxes at Jepara, Indonesia. The study uses a quantitative approach with a population of individual taxpayers who are registered at the tax office of Jepara, Indonesia. The number of samples is obtained by 100 respondents using the Slovin formula. The sampling technique was a convenience sampling technique. The data analysis method used is multiple regression analysis and Moderated Regression Analysis (MRA). Based on the test, it is found that the quality of tax authorities service, understanding and knowledge of taxation, tax sanctions, tax socialization, taxpayer awareness and perceptions of tax effectiveness have an influence on taxpayer compliance. In addition, the employment status of Civil Servants is more compliant in paying taxes since their income tax has been routinely deducted by the employer on the paid income.

\section{Introduction}

Sources of domestic revenue that are used to finance government expenditures and national development include tax revenue and non-tax revenue. The largest source of revenue and income in the country and currently more than $70 \%$ of Indonesia's annual budget is financed from tax revenue. Apart from playing a role in the source of revenue and income, taxes also have a function to smoothen a quality state economy. Tax revenue is a major concern, many efforts have been made by the government, in this case the Directorate General of Taxes, to increase state revenue. Such as increasing the number of active taxpayers, expanding taxable objects, increasing certain tax rates, examining taxpayers, and increasing supervision. Tarjo and Kusumawati (2006) explain that the level of tax compliance is still low, as indicated by the small number of individuals who have taxpayer identification numbers and report annual tax. Several factors such as tax authorities' services in serving taxpayer compliance, understanding tax regulations, tax sanctions, socialization of taxation, taxpayer awareness, and perceptions of the effectiveness of the taxation system have the possibility of affecting taxpayer compliance in carrying out their obligations as citizens. Supadmi (2009) explains that to improve taxpayer compliance in fulfilling tax obligations, the quality of service must be improved by tax officers. Therefore, the quality of service needs to be improved to provide comfort and a good view of taxpayers. Tax officer services that are honest, cooperative, do not make it difficult, enforce tax rules, and do not disappoint taxpayers who are expected to be able to solve taxpayer compliance problems. Tax officers' hospitality and ease in the tax information system are included in the taxation service. Taxpayers have their own perceptions about the systems owned by the government. Prior to the renewal of the registration system and filling in the tax items via the internet, taxpayers must first come to the Tax Office to carry out all tax processes. With the existence of e-banking, drop box, e-registration, e-filing, it causes a good perception of the tax system to increase the compliance of taxpayers. In order to facilitate the taxation system and run well and be understood by the public, socialization regarding taxation is also very necessary. With this socialization,

* Corresponding author.

E-mail address: subadriyah.undip@gmail.com (Subadriyah)

(C) 2021 by the authors; licensee Growing Science, Canada doi: $10.5267 /$ j.ac. 2021.5 .002 
the public can better understand problems regarding taxation, the facilities that can be obtained, and better understand the regulations that are still changing frequently. With a good understanding, it is hoped that it can improve taxpayer compliance, so it can be said that providing socialization about taxation also has an important effect on taxpayers in carrying out their tax obligations. Besides that, the awareness factor of taxpayers needs to be addressed. The positive assessment of taxpayers on the implementation of state functions by the government will move the public to comply with their obligations to pay taxes, therefore taxpayer awareness is needed in increasing taxpayer compliance and taxpayer awareness (Jatmiko, 2006). Not all taxpayers also have good knowledge and understanding of taxation. In Indonesia, the knowledge and understanding of taxpayers is still quite low. The relatively low understanding of taxpayers can be seen from the fact that there are still taxpayers who do not understand the annual tax return. Although the tax service office has provided an integrated guidebook and service place that is always available to serve taxpayers with all their interests and problems (Ekawati \& Radianto, 2008). Public awareness and discipline is needed to understand and comply with tax obligations (Masruroh \& Zulaikha, 2013). This understanding includes filling out a tax return, paying taxes, calculating taxes, reporting on taxes. For criminal sanctions it can be in the form of a criminal fine, imprisonment, and imprisonment. Various types of tax sanctions imposed on taxpayers who violate tax regulations are considered burdensome for taxpayers so that many taxpayers are then reluctant to fulfill their tax obligations (Kusuma, 2014). In addition, the status of employment between civil servants or non-employees is considered to affect taxpayer compliance. Utami and Soerono (2012) state that tax authorities have an influence on the level of taxpayer compliance. In contrast to the research of Tiraada (2013) states that the quality of tax services does not have an effect on individual taxpayer compliance. In addition, Adiyati (2009) found that the socialization of tax regulations has an effect on individual taxpayer compliance. However, in contrast to Winerungan (2013) states that the socialization of tax regulations has no effect on individual taxpayer compliance. Furthermore, Fikriningrum and Syafruddin (2012) revealed that the perception factor of the effectiveness of the taxation system has a positive and significant effect on individual taxpayer compliance in paying taxes. In contrast to the research of Sutari \& Kusuma (2013), the perception factor of the effectiveness of the taxation system does not affect the compliance of an individual taxpayer in paying his taxes.

\section{Research Methods}

This type of research is quantitative research. The data were obtained from the first source of distributing questionnaires. The dependent variable in this study is individual taxpayer compliance. Meanwhile, the independent variables in this study include the quality of fiscal service, tax knowledge and understanding, tax sanctions, tax socialization, taxpayer awareness, and perceptions of the effectiveness of the taxation system. other than that job status as a moderating variable. The data used are primary data and secondary data. Primary data is data obtained directly from the original source and not through intermediary media (Sugiyono, 2017). while secondary data is data obtained indirectly through intermediary media, such as other people or documents (Sugiyono, 2017). The population in this study were individual taxpayers of employees in 2017 as many as 57,189 and non-employees as many as 26,683. By using the Slovin formula, a sample of 100 respondents was obtained using convenience a sampling technique. The method of data analysis is with multiple regression analysis which previously tested classical assumptions.

\section{Results}

The characteristics of the respondents involved in this study can be seen in Fig. 1.

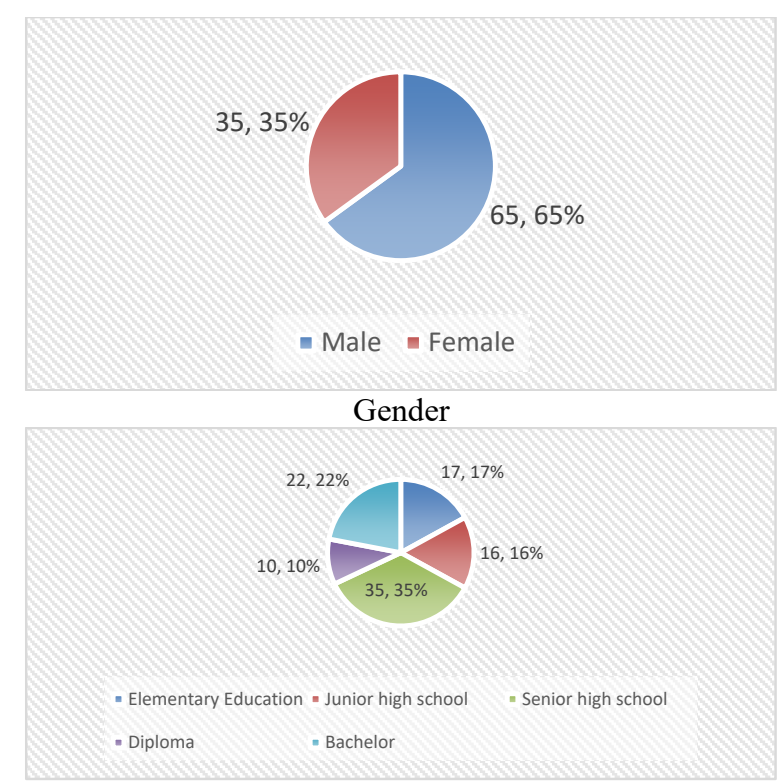

Education

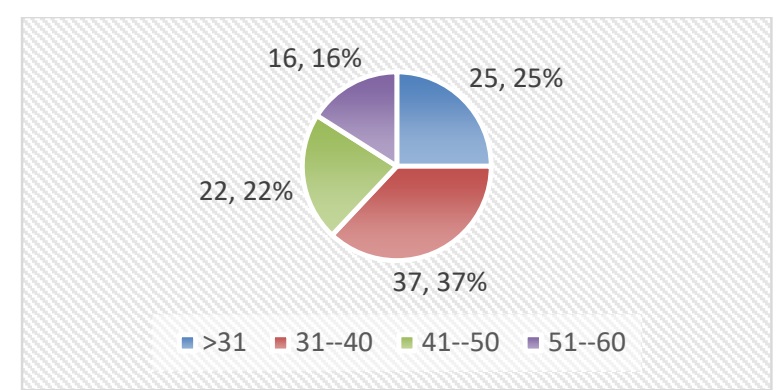

Age

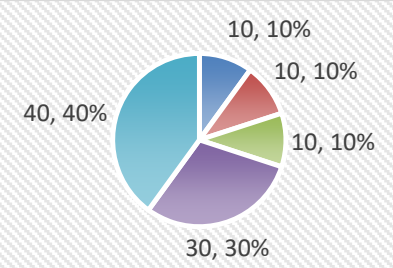

- Labor - Farmer - Traders - Entrepreneur - Civil Servant

Profession 
Fig. 1. Characteristics of Respondents

Respondents were represented by $65 \%$ male and $35 \%$ female. The majority of respondents as many as $37 \%$ were around the age of 31-40 years and 35\% graduated from high school education. The majority of respondents as much as $40 \%$ work as civil servants. Before the regression test was carried out, the classical assumption test was carried out. This research has passed the normality, multicollinearity and heteroscedasticity tests. The results of the regression test are in Table 1.

Table 1

Multiple Regression Analysis

\begin{tabular}{llll}
\hline Model & Regression Coefficient B & T & Sig. \\
\cline { 2 - 4 } & & & \\
\hline X1 Constant) & 2.135 & 2.017 & .045 \\
X2 & .163 & 2.128 & .021 \\
X3 & .047 & 2.275 & .011 \\
X4 & .015 & 1.809 & .024 \\
X5 & .183 & 3.820 & .000 \\
X6 & .178 & 7.346 & .000 \\
\hline R Square & .639 & & \\
Adj R Square & .924 & & \\
F-Value & .920 & & \\
Sig & 189,526 & & \\
Durbin Watson & 0,000 & &
\end{tabular}

Table 1 shows that each variable has a t count greater than $t$ table (1.661) and the sig value of each variable is less than 0.05 so it can be concluded that partially the service quality of fiscal, tax understanding and knowledge, sanctions taxation, taxation socialization, taxpayer awareness, and perception of the effectiveness of the taxation system affect individual taxpayer compliance. The calculated $\mathrm{F}$ value obtained is 189.526 , this shows that it is greater than $\mathrm{F}$ table $(2.20)$ and the significant value is less than 0.05 so that it can be concluded simultaneously the service quality of fiscal, tax understanding and knowledge, sanctions taxation, taxation socialization, taxpayer awareness, and perception of the effectiveness of the taxation system affect individual taxpayer compliance. The R-Square value is obtained at 0.924 meanwhile, the value of Adjusted R Square is 0.920 or $92 \%$. This means that it is $92 \%$. Individual taxpayer compliance in paying taxes is influenced by the quality of tax services, tax understanding and knowledge, tax sanctions, tax socialization, taxpayer awareness and perceptions of the effectiveness of the taxation system, while the remaining $8 \%$ compliance of individual taxpayers in paying taxes is influenced by other variables not included in this study. The test results show that the durbin watson (d) value is 2.175 , the dU value is 1.80306 , the $\mathrm{dL}$ value is 1.54958 and the value (4-d) is 1.825 . So it can be concluded that there is no autocorrelation because the value of $\mathrm{d}>\mathrm{dU}$.

Table 2

MRA analysis

\begin{tabular}{llll}
\hline Model & Regression Coefficient & $\mathrm{t}$ & \\
\hline (Constant) & 6.003 & 1.698 & .982 \\
X1 & 0.181 & 1.982 & .005 \\
X2 & 0.089 & 2.841 & .029 \\
X3 & 0.128 & 2.678 & .041 \\
X4 & 0.098 & 4.349 & .003 \\
X5 & 0.241 & 2.915 & .009 \\
X6 & 0.570 & 2.153 & .000 \\
X7 & 0.869 & 1.789 & .003 \\
X1.X7 & 0.025 & 1.949 \\
X2.X7 & 0.096 & 3.458 \\
X3.X7 & 0.174 & 2.855 \\
X4.X7 & 0.120 & 1.738 \\
X5.X7 & 0.094 & \\
X6.X7 & 0.158 & .039 \\
\hline R Square & 0.931 & .032 \\
Adj R Square & 0.920 & .045 \\
F-Value & 88.708 & .048 \\
Sig & 0,000 & .005 \\
Durbin Watson & 2,161 & .002 \\
\hline
\end{tabular}

Table 2 shows that each variable has a $t$ count greater than $t$ table (1.661) and the sig value of each variable is less than 0.05 , so it can be concluded that partially the independent variable affects the dependent variable. From the table above, it is known that the interaction between each independent variable and the moderating variable, namely job status, has a significance level that is smaller than 0.05 . This means that the job status variable is a moderating variable that is able to moderate the relationship between the independent variable and the dependent variable in this study. The calculated $\mathrm{F}$ value obtained is 88.708 , 
this shows that it is greater than F table (2.11) and the significant value is less than 0.05 so it can be concluded that simultaneously the independent variable affects the dependent variable. The R-Square value is obtained at 0.931 meanwhile the value of Adjusted R Square is 0.920 or $92 \%$. It can be concluded that the existence of a variable job status (moderating variable) can strengthen the relationship of each independent variable to the dependent variable. The test results showed that the Durbin Watson (d) value was 2.161, the dU value was 1.82619, the dL value was 1.52793 and the value (4-d) was 1.839 . So, it can be concluded that there is no autocorrelation because the value of $\mathrm{d}>\mathrm{dU}$. The results of the test show that the quality of tax authorities has a positive and significant effect on individual taxpayer compliance in paying taxes. This is because the significance value obtained is smaller than the alpha value $(\alpha=0.05)$. This research is in line with research conducted by Pranadata \& Rosidi (2014), Sutari \& Kusuma (2013) which explain that the quality of taxpayer services has a positive and significant effect on taxpayer compliance. This means that good and responsive tax authorities services provided to taxpayers fully affect taxpayer compliance in fulfilling their tax obligations. If the quality of the tax authorities service is good and as expected. This can be the main capital and an important thing to be able to attract the attention of taxpayers. The higher the quality of tax services, the more taxpayer compliance will be increased. The testing has also shown that tax understanding and knowledge has a positive effect on individual taxpayer compliance in paying taxes. This is evidenced by the significance value obtained which is smaller than the alpha value $(\alpha=0.05)$. The higher the understanding of the taxpayer's tax regulations on the taxation regulations, the more taxpayer compliance will be in paying their taxes. However, this study is not in line with the research of Asbar (2014) and Masruroh \& Zulaikha (2013) which states that the understanding of tax regulations has a significant effect on taxpayer compliance. Regarding the effect of tax sanctions on individual taxpayer compliance, the results showed that tax sanctions have a positive and significant effect on individual taxpayer compliance in paying taxes. This is evidenced by the significance value obtained which is smaller than the alpha value $(\alpha=0.05)$. The results of this study explain that the higher the tax sanctions given, the higher the level of taxpayer compliance in paying their tax obligations. The indicators used in this research are administrative sanctions and criminal sanctions which will be able to increase taxpayer compliance in carrying out their tax obligations. The results of this study are in line with Utami \& Kardinal (2013), Brata, Yuningsih, \& Kesuma (2017), Indriyani \& Sukartha (2014) which state that tax sanctions have a positive and significant effect on individual taxpayer compliance.

In the influence of taxation socialization on individual taxpayer compliance, the test results show that the Socialization of Taxation has a positive and significant effect on individual taxpayer compliance in paying taxes with a significance value that is less than the alpha value $(\alpha=0.05)$. This is in accordance with the research of Binambuni (2013) and Ari (2011) which explains that tax socialization has a positive and significant effect on taxpayer compliance. Taxation socialization is an effort by the Director General of Taxes, to be able to provide explanation, information and guidance to the public regarding everything related to taxation. If the tax service office regularly conducts counseling or socialization, the level of taxpayer compliance will be higher or get a good response from taxpayers when compared and later it will be better when compared to tax service offices that do not socialize taxation to the surrounding community, especially for taxpayers. The test results show that the taxpayers' awareness has a positive and significant effect on individual taxpayer compliance in paying taxes with a significance value smaller than the alpha value $(\alpha=0.05)$. The higher the level of awareness of taxpayers, especially individual taxpayers, the more obedient the taxpayer will be in carrying out and fulfilling their obligations. The results of this study are in line with research conducted by (Andinata, 2015; Cahyaputra \& Arianto, 2013; Harjanti \& Zulaikha, 2012; Mutia, 2014; Tanilasari \& Pujo, 2017) which explains that awareness of taxpayers has a positive and significant effect on mandatory compliance. personal tax. The perception of the effectiveness of the taxation system has a positive and significant effect on individual taxpayer compliance in paying taxes, with the significance value being smaller than the alpha value $(\alpha=0.05)$. Taxpayers who have positive perceptions in the taxation system will also be more obedient to taxpayers in carrying out their tax obligations, this can occur because perceptions can be expressed as a process of interpretation, organizing stimulus by individuals or organizations so that it is a meaningful thing and constitutes an integrated activity within the taxpayer. The results of this study are in accordance with the research of Fikriningrum \& Syafruddin (2012) which reveals that the perception factor of the effectiveness of the taxation system has a positive and significant effect on individual taxpayer compliance in paying taxes. Finally, based on the testing of job status variables, it can strengthen the relationship between the variable fiscal service quality, tax understanding and knowledge, tax sanctions, tax socialization, taxpayer awareness, and perceptions of the effectiveness of the taxation system on taxpayer compliance.

\section{Conclusion}

Based on the results of the analysis, it can be concluded that partially the tax authorities service quality, understanding and knowledge of taxation, tax sanctions, tax socialization, taxpayer awareness and perceptions of tax effectiveness have an influence on taxpayer compliance. The better the services provided, the more positive impact the taxpayers will have in carrying out their obligations in paying taxes and the higher the understanding of the taxpayer's tax regulations on taxation regulations, the more taxpayer compliance will be in paying their taxes. The higher the tax sanctions provided, the taxpayer compliance level will increase. In addition, job status can moderate the relationship between the independent variable and the dependent variable. Employment status with public sector employees is considered to be more compliant in paying taxes because their income tax has been routinely deducted by the employer on the paid income. 


\section{References}

Adiyati, T. (2009). The Influence of Taxation Socialization on the Compliance Level of Taxpayers at the Jakarta Kebayoran Lama Tax Office (National Development University Thesis).

Andinata, C. M. (2015). Analysis of Factors Affecting Individual Taxpayer Compliance in Paying Taxes (Case Study at the Surabaya Rungkut Primary Tax Service Office in Surabaya). University of Surabaya Student Scientific Journal, 4 (2).

Ari, S, A. (2011). Analysis of the Influence of Tax awareness, Rational Attitudes, Environment, Penalties, and Fiscal Attitudes on Taxpayer compliance. Thesis FE UNDIP Semarang.

Asbar, A. K. (2014). The influence of the level of service satisfaction, understanding of taxation, tax justice, tax sanctions and tax awareness on the level of compliance of individual taxpayers. Jom Fekon, 1 (2).

Binambuni, D. (2013). The Socialization of PBB Effect on Taxpayer Compliance in Karatung Village, Nanusa District, Talaud Regency. Emba Journal, 1 (4), 2078-2087.

Brata, J. D., Yuningsih, I., \& Kesuma, A. (2017). The Influence of Taxpayer Awareness, Fiskus Services, and Tax Sanctions on Individual Taxpayer Compliance Conducting Business Activities and Free Work in Samarinda City. Economic Forum, $19(1), 69$.

Cahyaputra, C., \& Arianto, A. (2013). Factors Affecting Taxpayer Compliance in Fulfilling Tax Obligations in Surabaya. Tax and Accounting Review, 1 (1), 41-48.

Ekawati, L., Radianto, \& EW., D. (2008). Survey of Understanding and Compliance of Small and Medium Business Taxpayers in Yogyakarta City. Accredited Journal of Information Technology and Management, 6, 185-190.

Fikriningrum, W.K, \& Syafruddin, M. (2012). Analysis of Factors Affecting Individual Taxpayers in Fulfilling Tax Obligations (Case Study at the Semarang Candisari Pratama Tax Office). Diponegoro Journal of Accounting, 1 (1), 567-581.

Harjanti, P., \& Zulaikha. (2012). The Influence of Taxpayer Awareness, Fiskus Services, and Tax Sanctions on Individual Taxpayer Compliance with Business Activities and Free Work (Study in the KPP Pratama Cilacap Area). Diponegoro Journa of Accounting, 1 (1), 1-8.

Indriyani, P. A., \& Sukartha, I. M. (2014). Moral Responsibility, Taxpayer Awareness, Tax Sanctions and Service Quality on Corporate Taxpayer Reporting Compliance. Udayana University Accounting E-Journal, 7 (2), 431-443.

Jatmiko, A. N. (2006). The Influence of Taxpayer Attitudes on the Implementation of Fines, Tax Service Officers and Tax Awareness of Taxpayer Compliance (Empirical Study of Individual Taxpayers in Semarang). (Thesis, Diponegoro University).

Kusuma, K. C. (2014). The Effect of Tax Service Quality, Understanding of Tax Regulations and Tax Sanctions on Individual Taxpayer Compliance in Paying Taxes. (Thesis Yogyakarta State University).

Masruroh, S., \& Zulaikha. (2013). Effect of NPWP Benefit, Taxpayer Understanding, Service Quality, Tax Sanctions on Taxpayer Compliance (Empirical Study on WPOP in Tegal Regency). Diponegoro Journal of Accounting, 2 (4).

Mutia, S. P. T. (2014). The Influence of Tax Sanctions, Tax Awareness, Fiscal Service, and the Level of Understanding of Individual Taxpayer Compliance (Empirical Study of Individual Taxpayers registered at KPP Pratama Padang). Journal of Accounting, 2 (1).

Pranadata, I. G. P., \& Rosidi. (2014). The Influence of Taxpayer Understanding, Tax Service Quality, and Implementation of Tax Sanctions on Individual Taxpayer Compliance at the Batu Pratama Tax Service Office. FEB Student Scientific Journal, 2 (2).

Sugiyono. (2017). Statistics for Research. Bandung: Alfabeta.

Supadmi, N. L. (2009). Improve Taxpayer Compliance through Service Quality. JIAB, 4 (2), 1-14.

Sutari, W., \& Kusuma, D. (2013). Influencing Factors Affecting Willingness to Pay Taxes as Manifestation of Civil Society. Proceedings of the National Seminar

Tanilasari, Y., \& Pujo, G. (2017). The Influence of Taxpayer Awareness and Quality of Fiskus Service on Individual Taxpayer Compliance at the Pratama Tax Service Office of South Malang. Journal of Accounting and Taxation, 3 (1), 1-9.

Tarjo, \& Kusumawati, I. (2006). Analysis of Individual Taxpayer Behavior Against Self-assessment System Study in Bangkalan. JAAI, $10(1), 101-120$.

Tiraada, T. A. (2013). Tax Awareness, Tax Sanctions, Fiskus Attitude towards WPOP Compliance in South Minahasa Regency. EMBA Journal, 1 (3).

Utami, S. R., \& Soerono, A. N. (2012). The Influence of External Factors on the Level of Taxpayer Compliance in the Serang Serang Tax Office Environment. Journal and Proceeding SNA-National Accounting Symposium, 15, 1-28.

Utami, T. D., \& Cardinal. (2013). The Influence of Taxpayer Awareness and Tax Sanctions on Individual Taxpayer Compliance at the Palembang Seberang Ulu Primary Tax Service Office. (Thesis of the Multi Data Economic College Palembang).

Winerungan, O. L. (2013). Tax Dissemination, Fiscal Service and Tax Sanctions on Wpop Compliance in Kpp Manado and Kpp Bitung. EMBA Journal, 1 (3). 
(C) 2021 by the authors; licensee Growing Science, Canada. This is an open access article distributed under the terms and conditions of the Creative Commons Attribution (CC-BY) license (http://creativecommons.org/licenses/by/4.0/). 